\title{
EDITORIAL
}

\section{Vinhos, chás, livros e a imprensa: A formação e a deformação dos cânones literários}

Felipe Pena'

O carro de luxo cruzou a avenida Saint Germain e dobrou na rua Monge. O motorista, vestido com um impecável terno azul e o indefectivel quepe com bordas de acrílico na cabeça, olhou discretamente pelo retrovisor. O patrào admirava o bracelete de diamantes usado pela mulher, enquanto balbuciava algumas palavras sobre o tempo frio e seco do inverno local. A neve dos anos anteriores ainda não começara a cair. Talvez nem começasse. Eifeito estufa. Gás carbônico. Sei lá! As questôes ecológicas nào interessavam à patroa. Nem ao chofer.

As rotações do motor denunciavam a reduçào da marcha para a subida do antigo Monte Santa Genoveva. Passaram pela Rue des Écoles, pela praça Cardinal Lemoine e pela arena romana, um dos pouco vestígios da velha cidade de luutécia. Ao chegarem à rua Saint-Médard, viraram à direita e pararam em frente ao que parecia ser um restaurante ou uma casa de vinhos. $O$ atendente veio recebélos à porta.

- Bonjour Madame. Bonjour Monsieur. Vieram para a degustação?

Madame e Monsieur se limitaram a balançar a cabeça positivamente. Atravessaram a porta de vidto e escolheram a mesa ao lado do longo balcão de madeira cujo brilho chegava a espelhar o revestimento rústico do teto. O lugar era pequeno, mas o pé-direito alto dava a impressão de amplitude ao espaço. Centenas de latas estavam arrumadas nas prateleiras espalhadas pela parede de seis metros de altura por doze de largura, onde também havia pequenos bules e xícaras de terracota.

O garçom se aproximou e forneceu um cardápio para cada cliente. As outras mesas estavam vazias. O casal desfrutava de atendi-

1 Jomalista c cscritor. Professor do Doutorado em Comunicação da UFF, Doutor cm Litcratura pela PUC-Rio e Pós-Doutor pela Universite de Paris - Sorbonne III. Autor de vito livios wa árca de Comunicação c do romance "O Analfabcto que passou no vestibular". 
mento exclusivo, o que incluía não apenas a atenção completa como também explicações detalhadas sobre o menu, cujas dezoito páginas se limitavam a um só produto.

- Je voudrais...

O garçom percebeu o leve sotaque latino do cliente que deslizava os dedos pelo cardápio. Não era francês, tinha certeza. $O$ que, de fato, não fazia a menor diferença, já que o texto estava em mandarim. As únicas palavras que monsieur compreendeu foram as do título, referentes ao nome do estabelecimento: Maison des Trois Thés. Mesmo assim, fez sua escolha, envaidecido por demonstrar conhecimento do produto e pela pronúncia perfeita na língua de Mao Tsé Tung.

- Wen Shan Bao Zhong. O número quatro, por favor! É mais alegre do que o número três.

- Perfeitamente. - respondeu o garçom.

O chá escolhido levava o nome da proprietária da Maison, Madame Zhong, uma chinesa de 37 anos cuja fama internacional devia-se à mistura de plantas na composição das infusões servidas em seu bistrô parisiense. Personalidades do mundo inteiro passavam pela rua Saint-Médard apenas para provar aquelas ervas banhadas em água quente. A casa não servia qualquer outro produto. Nem pequenos tira-gostos eram permitidos. Nada devia interferir na degustação do chá.

O ritual também era importante. O garçom colocou um punhado da erva no pequeno bule de terracota, enquanto a água fervia no fogão de lenha ao lado. Cada cliente recebeu uma xícara e a explicação sobre o consumo, que era obrigatória mesmo para freqüentadores assíduos. A água fervente foi colocada no bule até transbordar. Em seguida, o garçom tampou o recipiente e esperou durante exatos trinta e sete segundos, tempo ideal da infusão, para servir o casal, que precisaria esperar quatro minutos e meio para sorver o líquido.

- Querido, a escolha foi perfeita.

- Eu sei. Já tinha ouvido falar dessa safra. Ela tem substância. Causa um estranhamento, é inovadora, experimental, sensível.

- A erva pertence a que gênero?

- É um gênero híbrido. Transita pelas margens. Rompe barreiras. Mas essa erva já pode ser considerada um novo clássico.

- Por quê?

- O New York Times deu o conceito máximo para a mistura. 
Não foi à toa que Madame Zhong colocou o próprio nome no chá.

- E o que o crítico do Le Monde disse?

- Nada ainda. Como o Times já publicou uma crítica, acho que ele nào vai escrever nada. Pelo menos, por enquanto. Mas eu li elogios em jornais alemães, espanhóis e até ingleses. Todos falam em novo clássico.

- Hummmm! Agora está ainda melhor.

- É verdade. O aroma é ótimo. Há um buquê de sol poente, um gosto romântico, um sentimento de vanguarda. É a desconstrução dos chás anteriores. Uma nova tendéncia jnfusiva.

- O palato fica encharcado. Sinto um anti-racionalismo, uma extraterritorialidade bem pertinho da garganta. As estruturas estão bem delineadas.

- Isso me lembra o Romané Conti que bebemos ontem.

- O de ontem cra 1956. Não era tão bom.

- Como não? Custa mais caro que as safras da década de quarenta.

- Émesmo?

- Ééceééééééééćéćceéééceééé!

- Incrivel. Devo ter comido alguma coisa que interferiu no gosto.

- Acho que foi o Manifesto.

- Deve ter sido. O tempero estava muito forte. Não dá para comer Manifesto em qualquer lugar.

- Nào dá mesmo.

E passaram a tarde na Maison des Trois Thés, degustando os cinqüenta mililitros do melhor chá que podiam beber. 
8 